\title{
No-till banana planting on crop residue mulch: effect on soil quality and crop functioning
}

\author{
Marc DoreL*, Steewy LAKHIA, Chloé PÉTÉTIN, Salah BouAmeR, Jean-Michel Risède
}

CIRAD-Persyst, UPR 26, Neufchâteau, 97130 Capesterre Belle-Eau, Guadeloupe, French West Indies, France dorel@cirad.fr
${ }^{*}$ Correspondence and reprints

Received 12 October 2008 Accepted 3 August 2009

Fruits, 2010 , vol. 65 , p. 55-68 (C) 2010 Cirad/EDP Sciences All rights reserved DOI: $10.1051 /$ fruits/20010001 www.fruits-journal.org

RESUMEN ESPAÑOL, p. 68

\section{No-till banana planting on crop residue mulch: effect on soil quality and crop functioning.}

Abstract -- Introduction. In the French West Indies, farmers generally consider that periodical soil tillage is necessary to increase soil porosity and maintain high yield. However, in the nontilled perennial banana plantations of the highlands, the soil exhibits better physical and biological properties than in the conventional banana plantations. To determine if tillage before banana planting is necessary for proper banana crop functioning and to assess the effect of tillage on soil quality, banana planting after conventional tillage was compared with no-till banana planting on crop residue mulch on an experimental plot. Materials and methods. Soil quality was assessed through indicators such as porosity, organic status, microbial biomass and structure of nematode communities. Crop functioning was assessed through plant growth, root distribution, and soil water and nitrogen availability. Results. We found that tillage reduced soil microbial biomass and the number of nematode functional guilds. Tillage had only a short-term effect on soil porosity and did not allow deeper extension of the root system. Although soil organic nitrogen mineralization was higher with conventional tillage, banana nitrogen nutrition was not better, probably because the high nitrogen fertilization offset the variations in availability of nitrogen from organic origin. We found that banana growth was better with no-till treatment. This could be explained by less drying out of soil due to the crop residue mulch left on the soil surface with no-till treatment. Conclusion. Relative to conventional tillage, no-till banana planting improved soil quality and crop performance.

France (Guadeloupe) / Musa (bananas) / soil biology / zero tillage / mulching / crop performance

\section{Plantation de bananiers sans travail du sol sur un paillis de résidus de culture : effet sur la qualité du sol et le fonctionnement de la culture.}

Résumé -- Introduction. Aux Antilles françaises, les planteurs considèrent généralement qu'il est nécessaire d'effectuer périodiquement un travail du sol pour régénérer la porosité du sol et maintenir un fort rendement. Cependant, dans les bananeraies pérennes d'altitude, le sol qui n'est jamais travaillé présente de meilleures propriétés physiques et biologiques que dans bananeraies conduites de manière conventionnelle. Pour déterminer si le travail du sol avant la plantation est nécessaire au bon fonctionnement d'une culture de bananiers et pour évaluer l'effet du labour sur la qualité du sol, une plantation de bananiers après travail du sol classique a été comparée à la plantation directe de bananiers sur un paillis de résidus de récolte en parcelle expérimentale. Matériel et méthodes. La qualité du sol a été évaluée par des indicateurs tels que la porosité, le statut organique, la biomasse microbienne et la structure des populations de nématodes. Le fonctionnement de la culture a été évalué par la croissance de la plante, la distribution des racines, et la disponibilité de l'eau et de l'azote du sol. Résultats. Nous avons constaté que le travail du sol a réduit la biomasse microbienne du sol et le nombre de guildes fonctionnelles de nématodes. Le travail du sol a eu seulement un effet à court terme sur la porosité du sol et n'a pas permis un enracinement plus profond. Bien que la minéralisation de l'azote organique du sol ait été plus élevée avec le travail du sol conventionnel, la nutrition en azote des bananiers n'a pas été meilleure, probablement parce que la fertilisation azotée élevée a compensé les variations de la disponibilité de l'azote d'origine organique. Nous avons constaté que la croissance des bananiers était meilleure dans le traitement sans travail du sol. Cela a pu être expliqué par un plus faible dessèchement du sol dû au paillis de résidus de récolte laissé sur la surface du sol pour le traitement sans travail du sol. Conclusion. Par rapport au travail du sol classique, une plantation sans labour a amélioré la qualité du sol et les performances de la culture.

France (Guadeloupe) / Musa (bananes) / biologie du sol / non-travail du sol / paillage / performance de culture 


\section{Introduction}

The detrimental effects of tillage on soil organic carbon stock and erosion risks have been demonstrated in numerous situations for annual crops and have led to the development of alternative techniques in place of conventional tillage [1]. No-tillage and minimum tillage techniques (conservation tillage) have been tested since the 1960s and shown to be efficient for reducing erosion and preserving soil organic carbon [2]. Yet, the effects of these techniques on yield and crop functioning seem to vary according to cultivation conditions [3-5]. With conservation tillage, crop residues left on the soil surface and the resulting higher soil moisture have variable effects on soil pathogens depending on their survival strategies or on establishment of microbial antagonism [68]. It is noteworthy that the beneficial effects of conservation tillage, in the short term, are not clearly established for soil quality indicators such as soil porosity [9], structure of nematode communities $[10,11]$, earthworm abundance and diversity [12], and microbial biomass [13].

In the conventional banana cropping systems of the French West Indies, soil is not tilled annually, but on average every five years when banana plots need to be replanted. Because of the low replanting frequency and the high structural stability of volcanic ash soils, tillage does not induce high erosion risks or markedly decrease soil organic matter content [14, 15]. Farmers generally consider that periodical soil tillage and banana plot replanting are necessary to increase soil porosity and maintain high yield. However, in the non-tilled perennial banana plantations of the uplands, the soil exhibits better physical and biological properties than in the conventional banana plantations [16, 17].

Here we asked the following questions: what are the short-term effects of the absence of tillage on soil quality and crop functioning? Is tillage necessary for the establishment of high yield banana crop? The hypothesis tested was that in banana cropping systems, conservation tillage practices have beneficial effects on soil quality and crop functioning. Banana planting with no-tillage on crop residue mulch was compared with planting with conventional tillage on an experimental plot. Crop functioning was assessed through plant growth, root distribution, and ability of soil water and nitrogen to meet plant requirements. Soil quality was assessed through the soil profile morphology and through ecologically relevant biological indicators such as microbial biomass and structure of nematode communities. Nematodes were considered because, beyond the fact they are the most abundant metazoan animals of soils and they exhibit an extreme diversity of terrestrial habitats - including the less fertile ones - they are susceptible to disturbances or changes in soils [18, 19]. Being present at various levels of the soil food web, they show a wide species richness that can be related to their critical role in soil system functioning, through their feeding strategies and their life history traits [20, 21]. Nematode faunal analysis thus allows diagnosing the soil food web condition [22-24].

\section{Materials and methods}

\subsection{Experimental site}

Our research was conducted on the CIRAD experimental station of Neufchateau in Guadeloupe $\left(61^{\circ} \mathrm{W}, 16^{\circ} \mathrm{N}\right.$; alt. $\left.250 \mathrm{~m}\right)$. Soils are volcanic ash soil classified as Andosol [25]. On the site, mean annual rainfall is $3500 \mathrm{~mm}$ and mean daily temperature varies from $21{ }^{\circ} \mathrm{C}$ to $25^{\circ} \mathrm{C}$.

The experiment was conducted from February to December 2007 on a 1-ha banana field. Before the experiment began, the field was left under sanitation fallow for one year to lessen the abundance of banana parasitic nematodes. The perennial grass Brachiaria decumbens was used as cover crop during the fallow. Soil characteristics were studied at the end of the fallow period (table I).

\subsection{Experimental design}

Two treatments were applied:

- A no-tillage treatment: Banana plants from tissue culture were planted in March 2007 
Table I.

Soil characteristics before treatment application.

\begin{tabular}{|c|c|c|c|c|c|c|c|}
\hline \multirow{2}{*}{$\begin{array}{l}\text { Soil depth } \\
\text { (cm) }\end{array}$} & C & $\mathrm{N}$ & \multirow[t]{2}{*}{$\mathrm{pH}$} & $\mathrm{Ca}$ & $\mathrm{Mg}$ & $\mathrm{K}$ & $\mathrm{Na}$ \\
\hline & & & & \multicolumn{4}{|c|}{$\left(\mathrm{mEq} \cdot 100 \mathrm{~g}^{-1}\right)$} \\
\hline $0-10$ & 5.80 & 0.54 & 6.67 & 7.13 & 3.63 & 2.65 & 0.10 \\
\hline 10-20 & 5.26 & 0.49 & 6.34 & 5.92 & 1.59 & 1.55 & 0.05 \\
\hline 20-30 & 5.01 & 0.46 & 6.06 & 3.01 & 1.67 & 1.18 & 0.08 \\
\hline
\end{tabular}

in 10-cm-deep spade holes on the mulch made up of the Brachiaria decumbens cover killed by glyphosate application. The mulch left on the soil surface amounted to $18.5 \mathrm{t}$ of dry matter per ha.

- A conventional tillage treatment: Banana plants from tissue culture were planted in March 2007 after glyphosate application on $B$. decumbens and two successive passes of a heavy spading machine $\left(\right.$ Tortella $\left.^{(}\right)$in February 2007 , which caused $B$. decumbens cover burying. During tillage, soil moisture was $80 \%$, which corresponded to field capacity for this soil [16].

These treatments were randomized in three blocks on $1000-\mathrm{m}^{2}$ elementary plots planted at a density of 1850 plants $\cdot \mathrm{ha}^{-1}$. After planting, fertilizers were applied each month (30 kg N and $60 \mathrm{~kg} \mathrm{~K} 20$ per ha). Weeds were controlled with herbicide (glyphosinate) applied according to weed growth. Weed control required four applications of herbicide in the conventional tillage treatment but only two applications in the no-tillage treatment, due to the effect of the mulch on weed seed germination.

\subsection{Soil quality}

Soil quality was assessed through the following measurements and observations at banana planting $\left(\mathrm{T}_{0}\right)$ and eight months later, at the banana flowering stage $\left(\mathrm{T}_{0}+8\right)$ :

- At banana planting, a 1-m-deep pit was dug in the center of each elementary plot. A $100-\mathrm{cm}$-wide and $60-\mathrm{cm}$-high grid with 10-cm-square meshes was vertically applied on the soil profile. After the morphological units of the soil profile were described [26], soil resistance was measured in each mesh of the grid with a pocket penetrometer $\left(0.78 \mathrm{~cm}^{2}\right.$ flat-tipped measuring pin). Three sets of four $100-\mathrm{cm}^{3}$ cylindrical core samples were taken in the plowed layer (Ap horizon): at the top $\left(\mathrm{Ap}_{1}\right)$, in the middle $\left(\mathrm{Ap}_{2}\right)$ and at the bottom $\left(A p_{3}\right)$. These samples were used to determine (i) the soil void ratio considering that soil specific gravity was 2.41 [16], (ii) soil microbial biomass according to the fumigation-extraction method [27], and (iii) organic $\mathrm{C}$ and $\mathrm{N}$ by automated dry combustion. Saturated soil hydraulic conductivity was determined in three locations in each elementary plot by the double ring method (Müntz infiltrometer).

- Eight months after banana planting, at the banana flowering stage, a 1-m-deep pit was dug in each elementary plot $50 \mathrm{~cm}$ from a banana plant. After root location was plotted on the soil profile, three sets of $100-\mathrm{cm}^{3}$ core samples were taken following the same methods as at banana planting to determine the void ratio, microbial biomass, and organic $\mathrm{C}$ and $\mathrm{N}$. In addition, soil nematodes were extracted by elutriation of $250-\mathrm{cm}^{3}$ soil samples [28]. After nematode identification to genus level, they were assigned to different trophic groups according to Yeates et al. [29] and classified along a colonizer-persister gradient (c-p values) following Bongers [30]. They were further allocated into functional guilds by the method of Bongers and Bongers [21]. Finally, according to Ferris et al. [22], we evaluated soil food web condition by calculating the following two indices:

- EI (Enrichment Index) $=100 \times[\mathrm{e} /$ $(\mathrm{e}+\mathrm{b})]$,

- SI (Structure Index) $=100 \times[\mathrm{s} /(\mathrm{s}+\mathrm{b})]$, with $\mathrm{e}=0.8 \mathrm{Fu}_{2}+3.2 \mathrm{Bac}_{1} ; \mathrm{b}=0.8 \mathrm{Fu}_{2}+$ $0.8 \mathrm{Bac}_{2} ; \mathrm{s}=0.8\left(\mathrm{Pr}_{2}\right)+1.8\left(\mathrm{Pr}_{3}+\mathrm{Fu}_{3}+\right.$ 
$\left.\mathrm{Bac}_{3}\right)+3.2\left(\mathrm{Om}_{4}+\mathrm{Pr}_{4}+\mathrm{Fu}_{4}+\mathrm{Bac}_{4}\right)+5$ $\left(\mathrm{Om}_{5}+\mathrm{Pr}_{5}+\mathrm{Fu}_{5}+\mathrm{Bac}_{5}\right)$, where $\mathrm{Fu}_{\mathrm{i}}=$ fungivores, $\mathrm{Bac}_{\mathrm{i}}=$ bacterivores, $\mathrm{Pr}_{\mathrm{i}}=$ predators, $\mathrm{Om}_{\mathrm{i}}=$ omnivores, $i$ varying from 1 to 5 along a colonizer-persister scale.

The enrichment index (EI) reveals the primary enrichment of the soil food web, and consequently the abundance and activity of opportunistic nematodes, which respond rapidly to variation in food resources. It concerns the lower levels of the soil food web, i.e., bacterial and fungal feeders that are primary detritus consumers. The structure index (SI) indicates the soil food web length and stability through the relative abundance of higher nematode trophic levels.

\subsection{Crop functioning}

\subsubsection{Banana growth and development}

The following data set was recorded on 20 plants in each elementary plot:

- monthly increase in pseudo-stem girth,

- flowering date of individual banana plant,

- number of fruits per bunch.

\subsubsection{Nitrogen availability}

Figure 1.

Soil profile at the planting time $\left(T_{0}\right)$ of bananas according to treatments with no-tillage and conventional tillage.
Soil mineral nitrogen content was determined colorimetrically after $\mathrm{N}$ extraction with a $1 \mathrm{~N} \mathrm{KCl}$ solution on a composite sample obtained by mixing 30 sub-samples

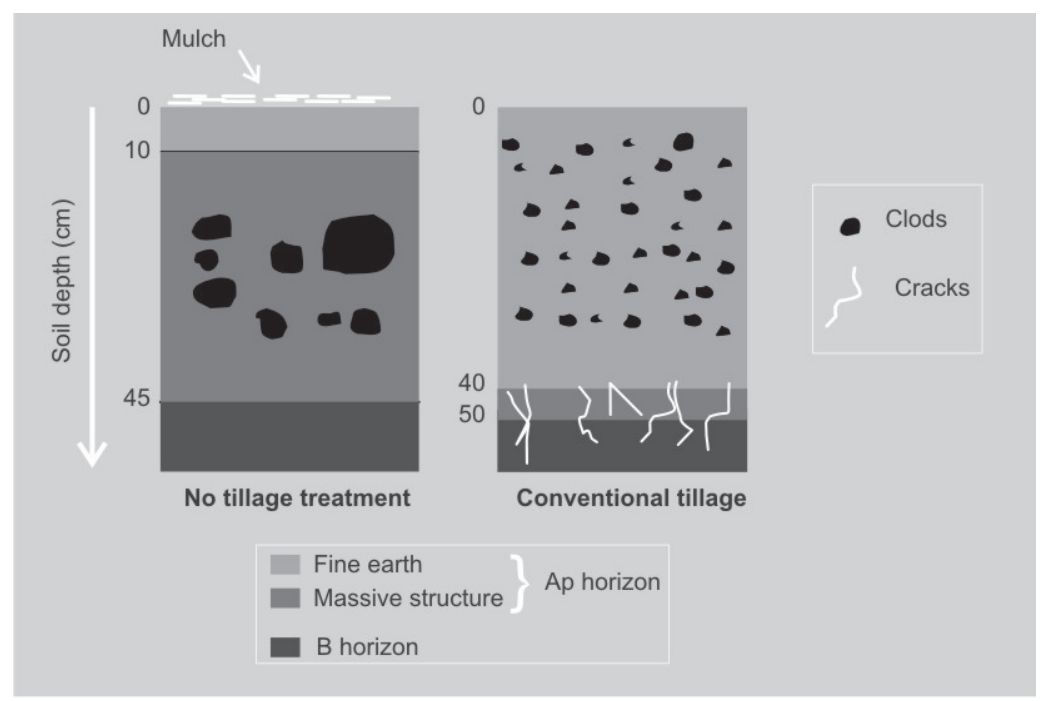

taken with an auger in the $0-\mathrm{cm}$ to $30-\mathrm{cm}$ layer. Sampling was performed one day before the monthly application of fertilizer in order to minimize the effect of fertilizer application on the measured soil nitrogen content.

Plant nitrogen nutrition was assessed monthly by readings through a chlorophyllmeter (SPAD-Minolta) on the last unfolded leaf of 10 plants in each elementary plot.

\subsubsection{Soil water availability}

Soil water tension was measured weekly with tensiometers placed at $-20 \mathrm{~cm}$ and $-40 \mathrm{~cm}$ underground in each elementary plot.

\subsection{Statistical analysis}

Variance analysis was carried out to assess the effect of treatments. Stepwise linear multiple regression was used in order to identify the most relevant soil quality indicators to explain crop performance. XLStat software was used for these analyses.

\section{Results}

\subsection{Soil quality}

\subsubsection{Soil profile description and penetration resistance}

Soil profiles observed for no-tillage treatment before banana planting (figure 1) showed that, under the mulch, there was a 10-cm layer exhibiting a well-developed structure made of millimetric granular aggregates (fine earth). The color of this layer went from black, in contact with the crop residue litter, to brown at the bottom of the layer (7.5YR 4.3 according to the Munsell color chart). From $10 \mathrm{~cm}$ to $45 \mathrm{~cm}$, soil structure became progressively massive but there were some decimetric clods revealing former soil tillage. In this layer, fine tubular pores of biological origin (root paths, etc.) were common. At $45 \mathrm{~cm}$, a clear boundary separated the Ap horizon from the brighter underlying $\mathrm{B}$ horizon (7.5YR4.6). The B 
horizon presented a massive structure with abundant fine to medium tubular pores.

Soil profiles observed for conventional tillage treatment before banana planting (figure 1) showed that, from $0 \mathrm{~cm}$ to $40 \mathrm{~cm}$, the soil exhibited a homogeneous fragmented structure made of small centimetric clods and fine earth resulting from spading. Between $40 \mathrm{~cm}$ and $50 \mathrm{~cm}$, the soil presented a massive structure with cracks that seemed to result from spade impacts [31]. Below $50 \mathrm{~cm}$ was the brighter $\mathrm{B}$ horizon described above.

The variation in soil penetration resistance with depth for no-tillage and conventional tillage treatments showed that the effect of tillage tended to decrease with depth but was still perceptible between $40 \mathrm{~cm}$ and $60 \mathrm{~cm}$ (figure 2), thus below layers moved by the spading machine. This observation could result from soil cracking below the impact point of the spades.

\subsubsection{Soil organic matter}

Although organic carbon and nitrogen content at banana planting $\left(\mathrm{T}_{0}\right)$ tended to be higher in the upper level of the Ap horizon of no-tillage treatment (figure 3), variance analysis did not show a significant effect of tillage or depth on these variables $(P>0.05)$.

\subsubsection{Soil biological properties}

\subsubsection{Microbial biomass}

Regarding soil microbial carbon content at the top, in the middle, and at the bottom of the Ap horizon at banana planting $\left(\mathrm{T}_{0}\right)$ and at the flowering stage $\left(\mathrm{T}_{0}+8\right)$, variance analysis showed a significant effect of the interaction of tillage, soil depth and date of sampling $\left({ }^{* *} P<0.01\right)$ (figure 4$)$. At $\mathrm{T}_{0}$, the highest microbial biomass was with no-tillage treatment at the top of the Ap horizon. With no-tillage, the microbial biomass decreased with depth while, with conventional tillage, microbial biomass did not differ at the three levels of the cultivated layer. At the $\mathrm{T}_{0}+8$ stage, microbial biomass strongly decreased with both treatments. However, microbial biomass was still significantly higher and decreasing with depth for

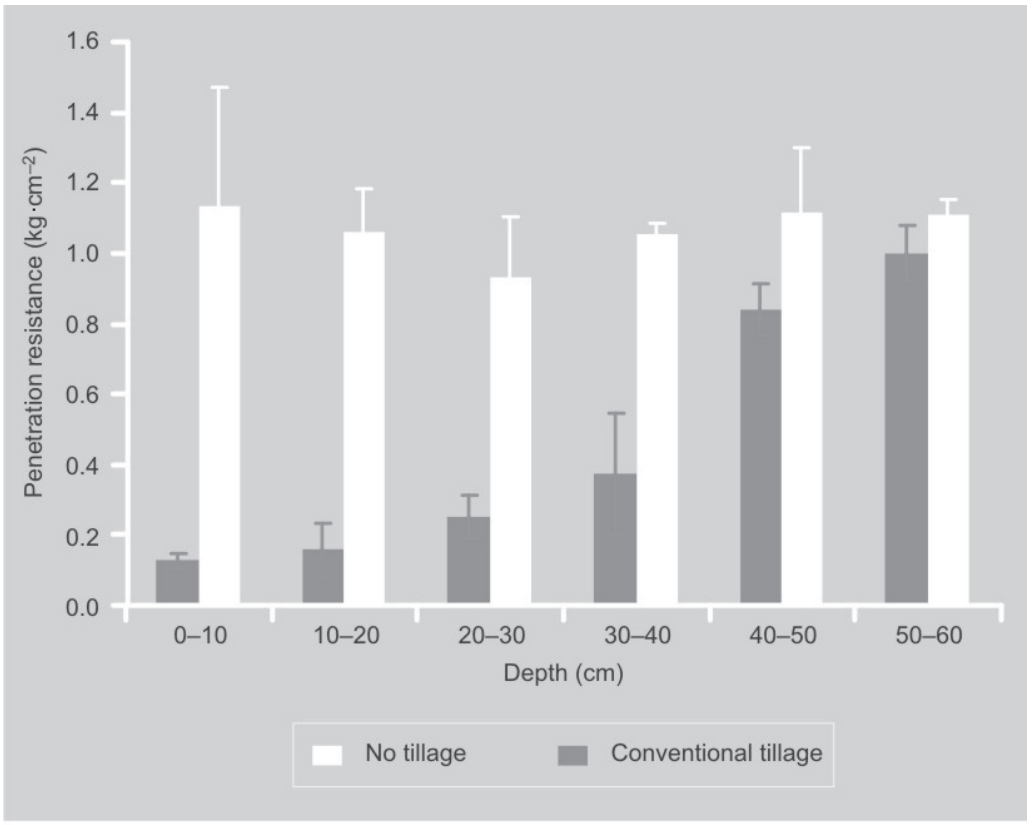

no-tillage, and it was lower and constant whatever the depth for conventional tillage treatment.

\subsubsection{Nematode functional guild and food web condition}

The number of functional guilds (nFG) varied significantly with tillage $\left({ }^{*} P<0.05\right)$ and soil depth $\left.{ }^{* * * *} P<0.001\right)$. In the upper (Ap1) and middle (Ap2) levels of the Ap horizon, nFG was higher for no-tillage treatment than for conventional tillage treatment (Ap1: $\mathrm{nFG}=14$ for no-tillage and $\mathrm{nFG}=9$ for conventional tillage; Ap2: $\mathrm{nFG}=11$ for notillage and $\mathrm{nFG}=\mathbf{8}$ for conventional tillage) mainly because of the lower number of predator and omnivore guilds (figure 5). At the bottom of the Ap horizon (Ap3), predator and omnivore guilds completely disappeared with both treatments (figure 5). In this layer, the bacterivore 1 guild corresponding to enrichment opportunistic nematodes was present in the no-tillage treatment but was absent in the conventional tillage treatment.

The planar representation of the soil food web conditions based on the structure index (SI) and the enrichment index (EI) indices shows that tillage had a significant effect on EI $(* * * P<0.001)$ but not on SI,
Figure 2.

Variation with depth of penetration resistance of soil in banana plantation according to treatments with no-tillage and conventional tillage. 


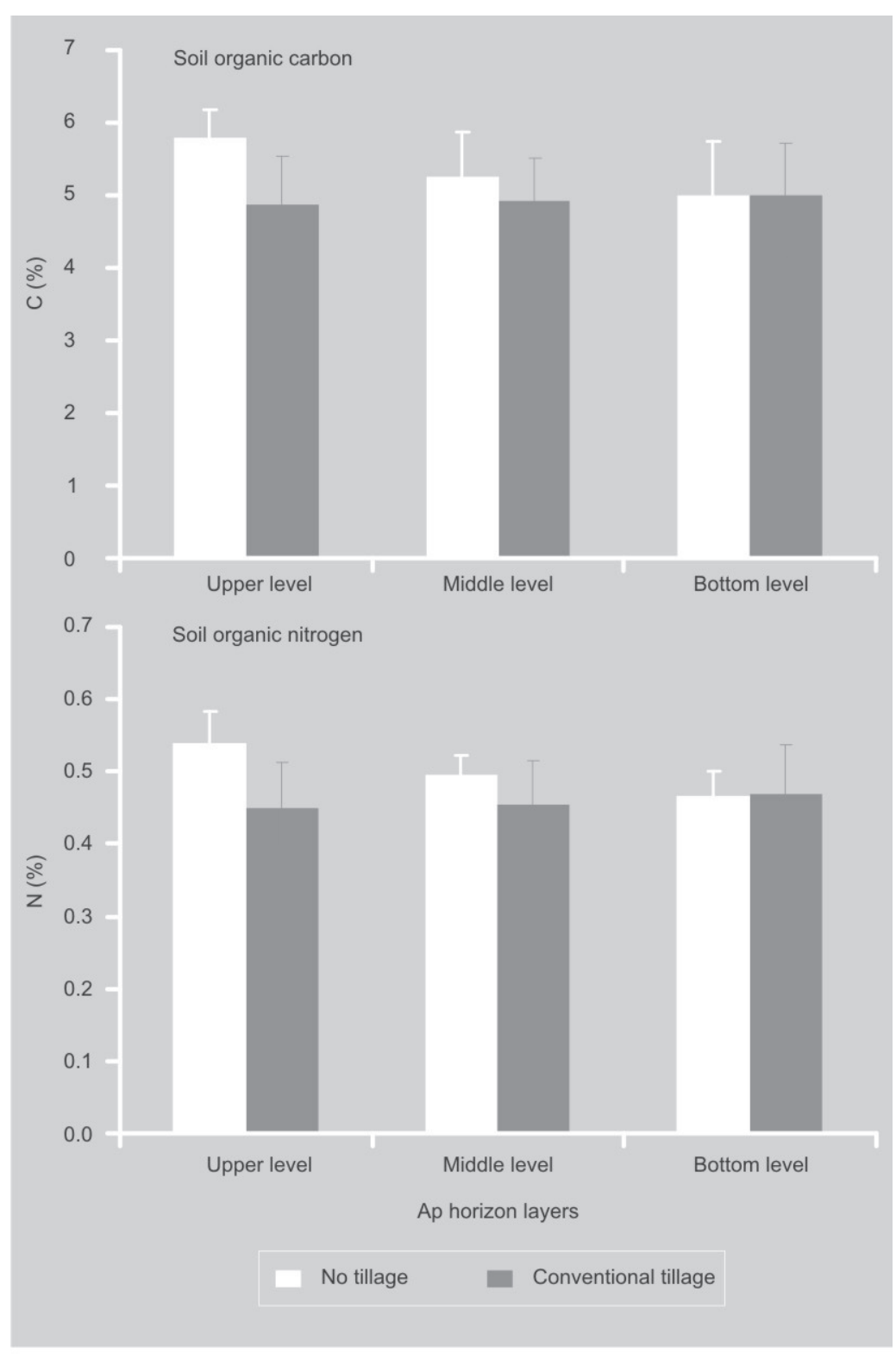

Figure 3.

Soil organic carbon and soil organic nitrogen in banana plantation at the banana planting time $\left(\mathrm{T}_{0}\right)$ according to treatments with no-tillage and conventional tillage. layer of the Ap horizon (Ap3), EI was high with no-tillage treatment but decreased markedly with conventional tillage treatment. This low EI in the Ap3 layer with conventional tillage treatment can be explained by the absence of bacterivore 1 guild nematodes (figure 5). In Ap3, SI values were markedly lower than in Ap1 and Ap2 with both tillage treatments. These low SI values reveal the absence of the upper level of the soil food web in this layer with no-tillage and conventional tillage treatments (figure 5).

\subsubsection{Porosity and hydraulic conductivity}

Variance analysis on data regarding the soil void ratio at banana planting $\left(\mathrm{T}_{0}\right)$ and at the flowering stage $\left(\mathrm{T}_{0}+8\right)$ in the upper (Ap1), middle (Ap2) and bottom (Ap3) layers of the Ap horizon revealed a significant effect of the interaction of tillage, depth and date of sampling $(* * * P<0.001)$ (table II). At $\mathrm{T}_{0}$, void ratios were significantly higher with conventional tillage treatment than with notillage treatment. Between the $T_{0}$ and $T_{0}+$ 8 stages, the Ap1 void ratio decreased markedly with conventional tillage treatment; in contrast, the Ap1 void ratio tended to increase slightly with no-tillage treatment. At $\mathrm{T}_{0}+8$, the Ap1 void ratio became lower with conventional tillage treatment than with no-tillage treatment. Note that, with conventional tillage treatment, the decrease in void ratio between the $\mathrm{T}_{0}$ and $\mathrm{T}_{0}+$ 8 stages was lesser in Ap2 and Ap3 than in Ap1.

At the $\mathrm{T}_{0}$ stage, the hydraulic conductivity of the conventional tillage soil was significantly higher than that of no-tillage soil (table III). However, the average hydraulic conductivity in no-tillage soil was near $20 \mathrm{~mm} \cdot \mathrm{h}^{-1}$, which is sufficient for infiltration of most of the rainfall events in the Neufchateau site [32]. Between the $\mathrm{T}_{0}$ and $\mathrm{T}_{0}+$ 8 stages, the hydraulic conductivity of the conventional tillage soil decreased markedly; at the $\mathrm{T}_{0}+8$ stage, the two treatments did not differ significantly. In fact, the soil hydraulic conductivity variation appears coherent with the void ratio variation in the superficial layer. 


\subsection{Crop functioning}

\subsubsection{Banana growth and crop productivity}

According to our results, banana growth, assessed by pseudo-stem girth increase, was better with no-tillage treatment (figure 7). Hence, with no-tillage treatment, pseudostem girth at the flowering stage was significantly higher (table IV). Average fruit number per bunch was higher and average flowering date was earlier in no-tillage treatment but the differences with conventional tillage treatment were not significant.

\subsubsection{Soil water tension}

Soil water tension increased with conventional tillage during the dry period occurring between weeks 16 and 28 after planting, reaching values over 500 mbars (figure 8). The same trend was observed with notillage but water tension values were lower. The differences between no-tillage and conventional tillage were more pronounced at $-20 \mathrm{~cm}$ than at $-40 \mathrm{~cm}$.

\subsubsection{Soil nitrogen availability}

Soil mineral nitrogen increased after planting with both tillage treatments. The increase was stronger for conventional tillage and resulted mainly from nitrate production (figure 9). Five months after planting, soil mineral nitrogen fell to low values with both treatments. With conventional tillage treatment, tillage disrupted aggregates and increased soil organic matter accessibility to microbes. Moreover, tillage improved soil aeration. Consequently, tilled soil conditions were more favorable to organic $\mathrm{N}$ mineralization than no-tilled soil $[9,33]$.

Banana nitrogen nutrition was assessed through banana leaf chlorophyll content (figure 10). Chlorophyll-meter readings were very close for the conventional tillage and no-tillage treatments, indicating that nitrogen nutrition levels were similar. It seems that higher soil nitrogen availability with conventional tillage treatment did not improve banana nitrogen nutrition.

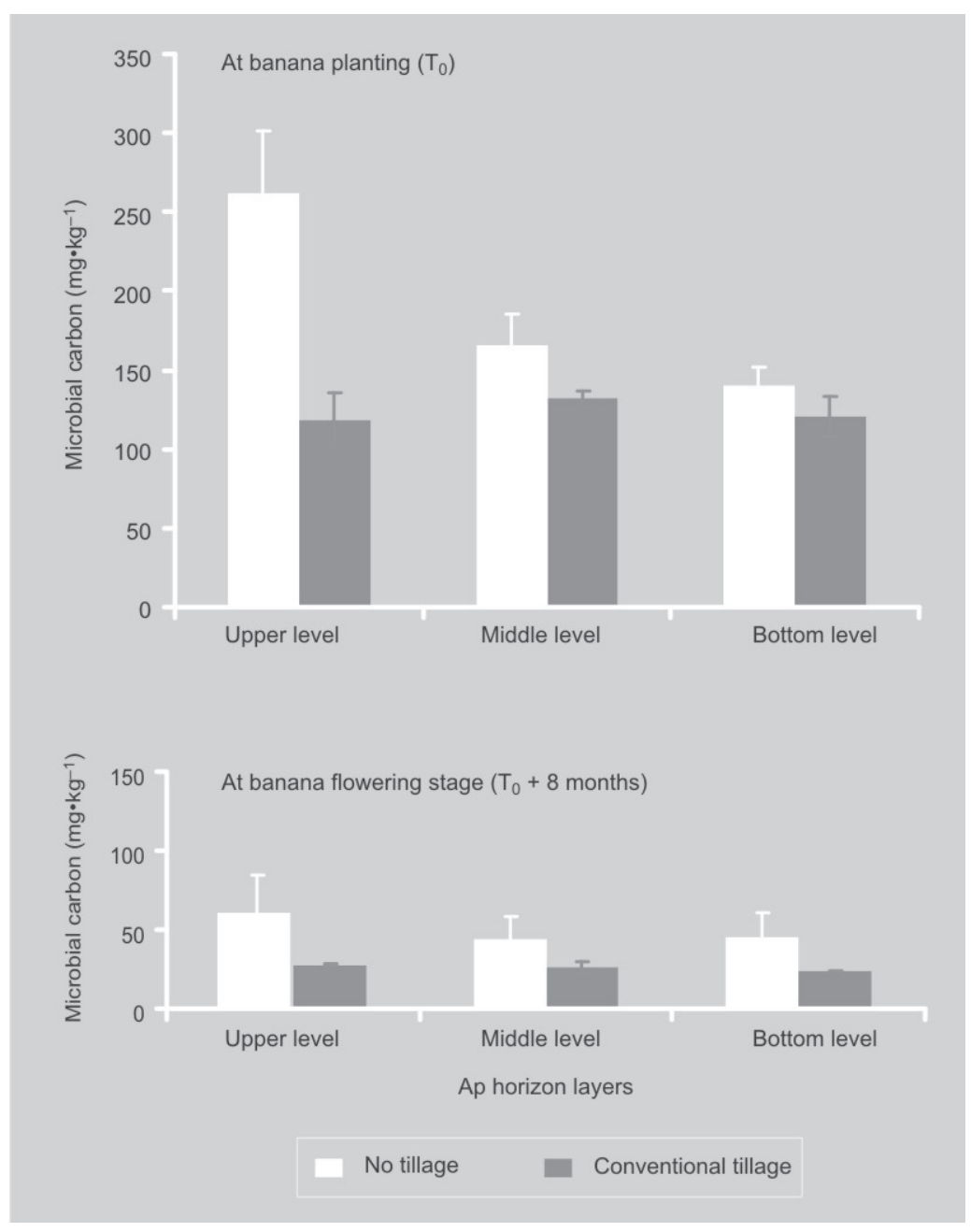

\subsubsection{Root distribution}

Although root density in the $10-\mathrm{cm}$ to $30-\mathrm{cm}$ layer tended to be higher with conventional tillage and maximum root depth tended to be higher with no-tillage, the root distribution in soil profiles did not differ markedly between no-tillage and conventional tillage treatments (figure 11).

It must be noted that necrosis caused by soilborne pathogens was not observed on the roots in no-tillage treatment as in conventional tillage treatment.

\subsubsection{Crop performance and soil quality}

The pseudo-stem girth (PG) of banana at the flowering stage was chosen as an indicator
Figure 4.

Comparison between soil microbial carbon with no-tillage and conventional tillage treatments at planting time $\left(\mathrm{T}_{0}\right)$ and at the flowering time eight months after $T_{0}\left(T_{0}+8\right)$. 


\section{Dorel et al.}

\section{Figure 5.}

Abundance of nematodes in each functional guild (after Log transformation) at the upper (Ap1), in the middle (Ap2) and at the bottom (Ap3) levels of the Ap horizon layers for no-tillage and conventional tillage treatments (for obligatory root feeders, fungivores,

bacterivores, predators and omnivores; the indices 1 to 5 correspond to a colonizerpersister scale).

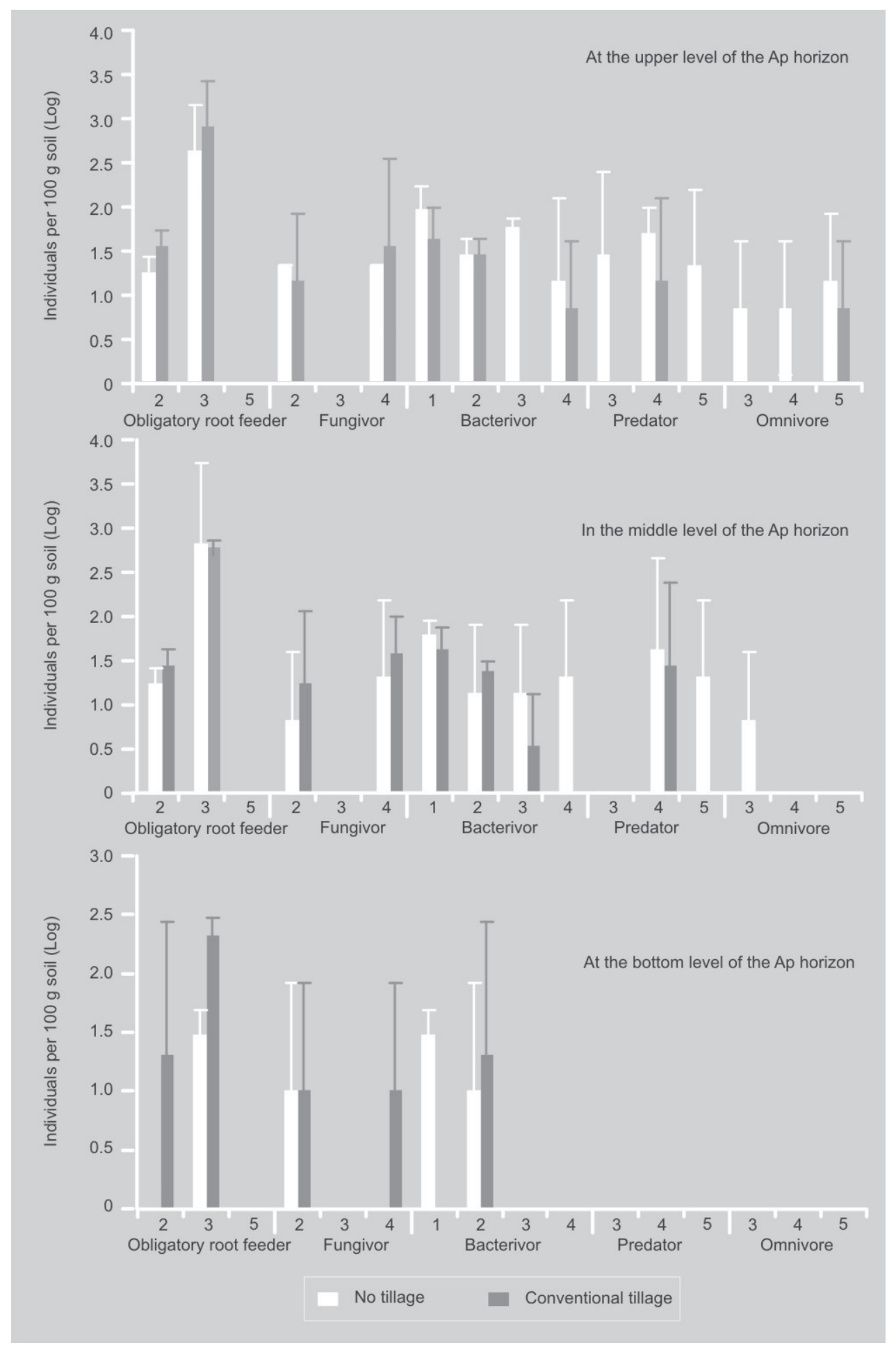


of crop performance. A stepwise linear multiple regression analysis was carried out to assess the influence of indicators of soil quality [porosity, hydraulic conductivity, penetration resistance, microbial biomass, nitrogen and carbon content, $\mathrm{pH}$, nematode food web indices (enrichment index, structure index), and functional guild number] on PG measured in the six elementary plots of our experiment.

The best linear model for PG prediction was obtained by combining the microbial biomass of the $0-10-\mathrm{cm}$ layer $\left(\mathrm{MB}_{0-10}\right)$ and nematode food web structure index (SI) as follows: $\mathrm{PG}=29.32+0.29 \mathrm{SI}+0.0581 \mathrm{MB}_{0-10}$ $\left(R^{2}=0.969\right)$.

\section{Discussion}

\subsection{Effect of tillage on soil quality}

Our results showed that soil porosity and soil hydraulic conductivity increased markedly immediately after tillage because of fragmentation of the massive structure. This effect disappeared 8 months after plantation. Soil structure degradation under conventional banana cropping was reported by Dorel [34] and explained by mechanical constraints applied on the wet bare soil when workers circulate in the banana field. At plantation, porosity was lower in no-till soil but tended to be slightly higher 8 months after. This tendency was probably due to high biological activity under crop residue mulch. Thus, tillage improves soil

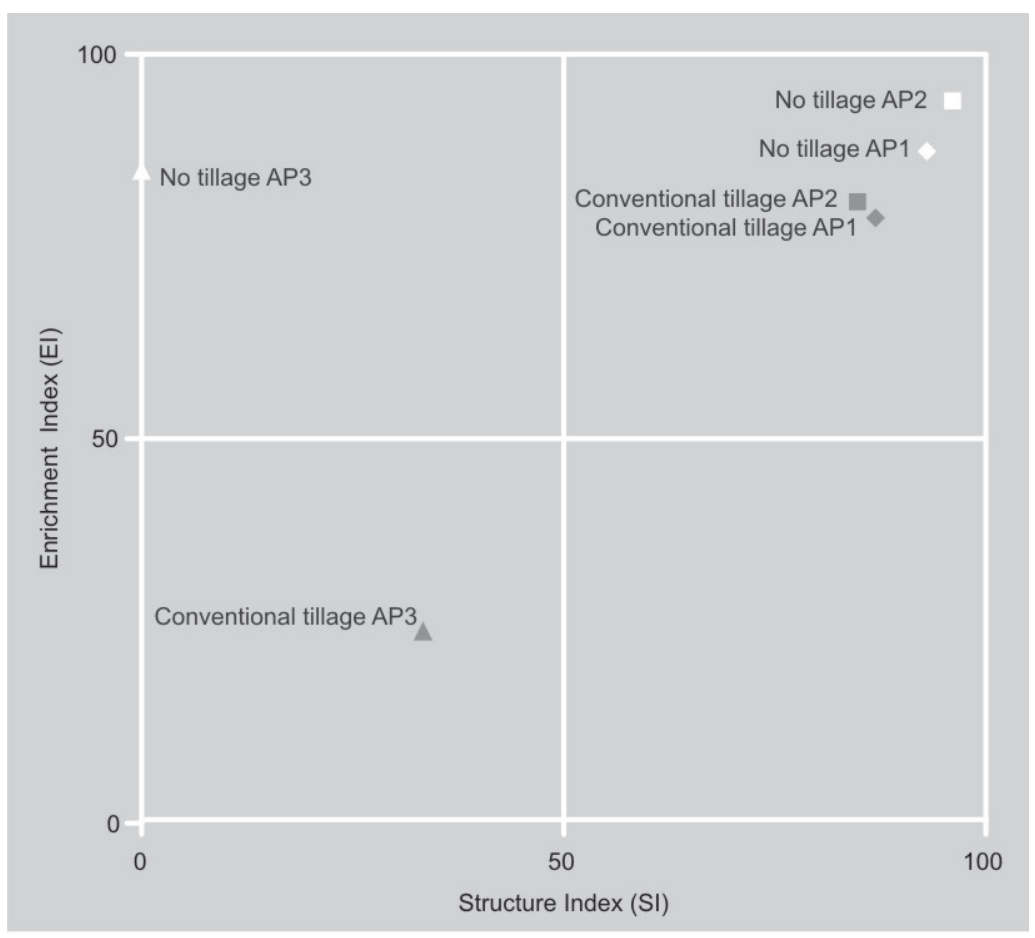

structure only in the short term, whereas notill seems to favor the development of biological porosity.

Between one and five months after plantation, we observed higher mineral nitrogen production with conventional tillage treatment. Tillage favors soil organic matter minFigure 6.

Structure index (SI) and enrichment index (EI) indices at the upper (Ap1), in the middle (Ap2) and at the bottom (Ap3) levels of the Ap horizon layers for no-tillage and conventional tillage treatments.

Table II.

Void ratio in the plowed layer: at the top $\left(A p_{1}\right)$, in the middle $\left(A p_{2}\right)$ and at the bottom $\left(A p_{3}\right)$, for conventional tillage and no-tillage treatments at banana planting $\left(T_{0}\right)$ and eight months later, at the banana flowering stage $\left(T_{0}+8\right)$.

\begin{tabular}{lcccc} 
Plowed layer & \multicolumn{2}{c}{ Void ratio at T0 } & \multicolumn{2}{c}{ Void ratio at T0 + 8} \\
& No-tillage & Conventional tillage & No-tillage & Conventional tillage \\
At the top & $2.54 \mathrm{~cd}$ & $3.30 \mathrm{a}$ & $2.80 \mathrm{bc}$ & $2.41 \mathrm{~d}$ \\
In the middle & $2.48 \mathrm{~cd}$ & $3.32 \mathrm{a}$ & $2.49 \mathrm{~cd}$ & $2.72 \mathrm{bcd}$ \\
At the bottom & $2.71 \mathrm{bcd}$ & $3.03 \mathrm{~b}$ & $2.52 \mathrm{~cd}$ & $2.70 \mathrm{bcd}$
\end{tabular}

Letters indicate groups significantly different according to the Newman-Keuls test. 
Table III.

Soil hydraulic conductivity with no-tillage and conventional tillage treatments $(n=3)$.

\begin{tabular}{|c|c|c|c|}
\hline \multicolumn{2}{|c|}{$\begin{array}{l}\text { Hydraulic conductivity at } \mathrm{T}_{0} \\
\qquad\left(\mathrm{~mm} \cdot \mathrm{h}^{-1}\right)\end{array}$} & \multicolumn{2}{|c|}{$\begin{array}{l}\text { Hydraulic conductivity at } \mathrm{T}_{0}+8 \\
\left(\mathrm{~mm} \cdot \mathrm{h}^{-1}\right)\end{array}$} \\
\hline No-tillage & Conventional tillage & No-tillage & Conventional tillage \\
\hline $18 \mathrm{~b}$ & $1852 \mathrm{a}$ & $44 \mathrm{~b}$ & $69 \mathrm{~b}$ \\
\hline
\end{tabular}

Letters indicate groups significantly different according to the Newman-Keuls test.

Figure 7.

Girth increase in banana pseudo-stem according to treatments with no-tillage and conventional tillage $(n=3)$.

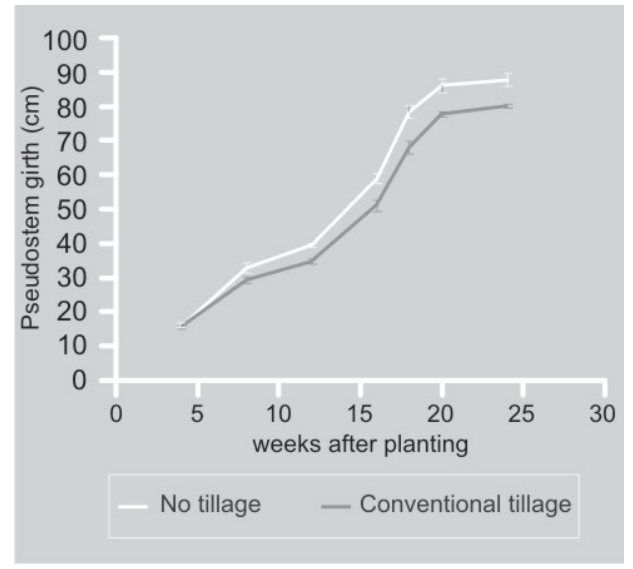

index values were the lowest with conventional tillage treatment. The enrichment index is related to resource availability [22] and in particular to the amount of organic nitrogen able to be degraded and mineralized by soil organisms [35, 36]. Enrichment index values were particularly low at the bottom (Ap3) of the tilled layer with conventional tillage treatment because tillage has probably drastically favored the access of organic matter to soil organisms in the deep layer of conventional tillage treat- ment, thus leaving a lesser residual resource availability in Ap3-conventional tillage than in Ap3-no-tillage.

Our experiment showed that tillage affected the size and distribution of the microbial biomass in the soil profile. However, tillage had no significant effect on soil organic matter content. In our experiment, no-tillage and conventional tillage treatments did not differ in long-term soil management; they differed only in mode of soil preparation before present crop establishment. Our results agree with those of Chaussod et al., reporting that soil organic matter content depended on long-term cumulated effects of crop management, whereas microbial biomass could change rapidly with recent modification of cultural practices [37].

In the surface layers, we found that tillage reduced nematode functional guild number and particularly affected the upper level of the soil food web (predators, omnivores). However, this reduction was low and had only a slight effect on the structure index which characterizes food web length. In a review concerning the effect of tillage effect on nematode communities, Okada and Harada noticed that many studies have found no effects of no-tillage on nematode communities, while others showed significant effects [10]. According to those authors, the absence of effect was observed in experiments in which no-tillage treatment was short ( $<1$ year). We compared here no-tillage and conventional tillage in an 8-month period, which could explain the weak effect we observed on nematode communities. However, in the case of banana crop, tillage is performed at most every 4 years and the cumulative effect of tillage in a long period could be lesser than with annual crops

Table IV.

Banana productivity indicators for no-tillage and conventional tillage treatments $(n=3)$.

\begin{tabular}{|c|c|c|c|}
\hline Treatment & $\begin{array}{c}\text { Flowering date } \\
\text { (weeks after planting) }\end{array}$ & $\begin{array}{l}\text { Pseudo-stem girth at flowering stage } \\
\qquad(\mathrm{cm})\end{array}$ & Fruit number per bunch \\
\hline No-tillage & 38.6 & 61 & 194.2 \\
\hline Conventional tillage & 39.5 & 57 & 175.9 \\
\hline Significance & Non-significant $(P=0.12)$ & Significant $^{\star \star}(P<0.01)$ & Non-significant $(P=0.07)$ \\
\hline
\end{tabular}


because nematode communities may recover between two successive disturbances by soil tillage.

\subsection{Effect of tillage on crop functioning}

The higher soil nitrogen availability with conventional tillage treatment did not result in better banana nitrogen nutrition, as assessed through chlorophyll-meter readings. The high level of nitrogen fertilization applied in banana crop (350 kg N.ha ${ }^{-1} \cdot$ year $\left.^{-1}\right)$ likely met the banana requirements largely and offset the effects of the lower nitrogen availability with no-tillage treatment.

The lower soil water tension with no-tillage treatment seems to result from the mulch effect which protects the soil surface from direct evaporation. High soil water tension during the driest period probably led to banana water stress, particularly with conventional tillage treatment. Dorel and Ozier-Lafontaine observed a progressive reduction of banana growth when soil water tension increased over 100 mbar [38]. A better water availability could contribute to explaining the better banana growth in notillage treatment. After analyzing numerous tillage experiments, Germon et al. [4] and Franzluebbers [5] reported that the beneficial effects of conservation tillage on plant growth are generally explained by a higher water availability related to the reduction of soil evaporation.

Although soil root growth conditions (porosity, penetration resistance, hydraulic conductivity) seemed better after tillage, colonization of the soil profile was not improved compared with no-tilled soil. Lecompte et al. reported that the reduction of air-filled porosity due to soil compaction affected banana root extension [39]. In notillage treatment, biological porosity generated during the fallow period under Brachiaria decumbens cover seemed sufficient for the banana root system to be properly established and soil loosening in conventional tillage treatment did not improve root growth conditions.

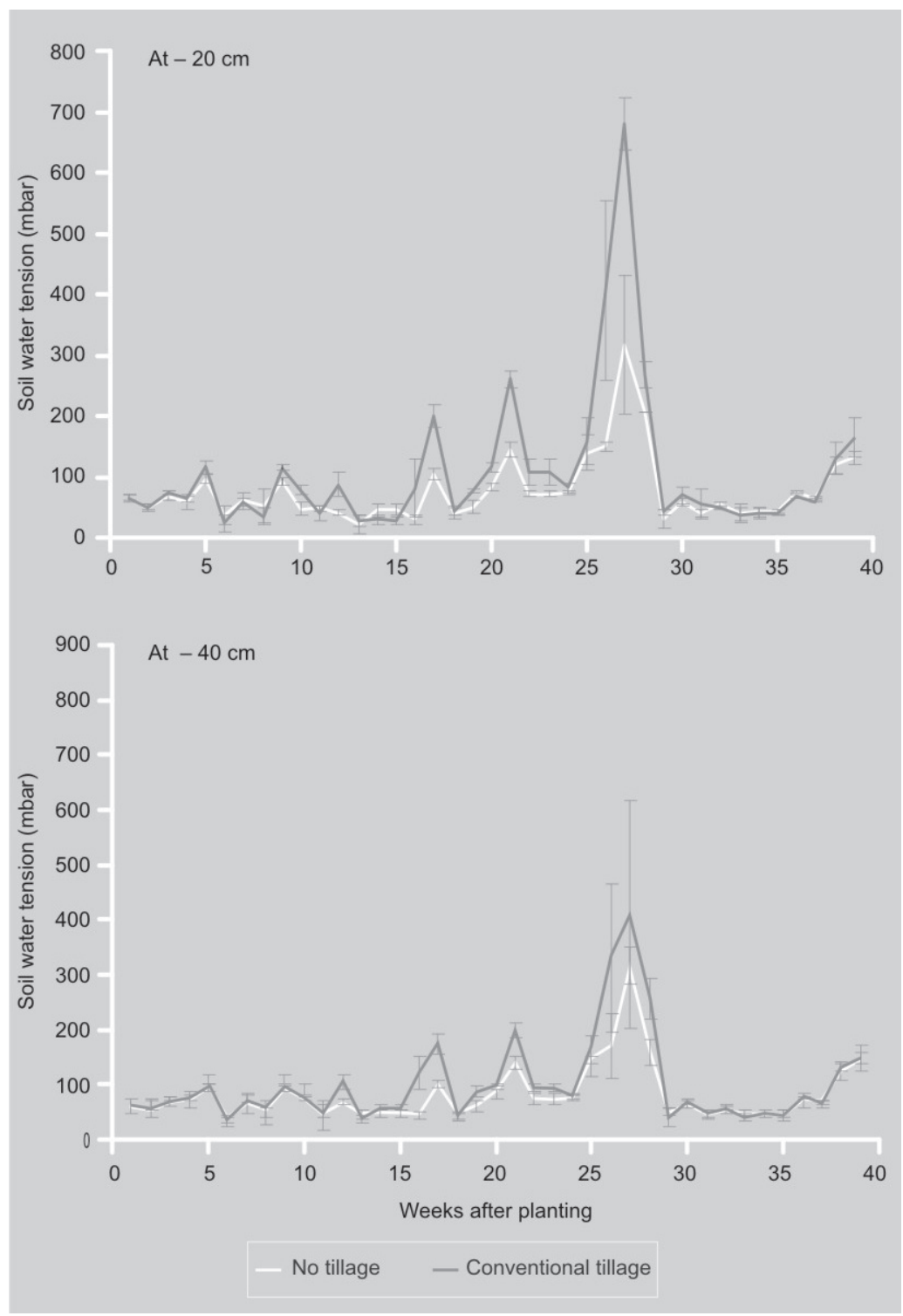

We found that banana pseudo-stem girth at the flowering stage could be predicted from indicators of biological soil quality such as microbial biomass and the food web structure index. These indicators were more relevant to explain crop performance than indicators of soil physical properties such as porosity, hydraulic conductivity or penetration resistance. These results suggest that the preservation of soil biological properties is more useful for banana crop performance than soil loosening by tillage.

\section{Figure 8.}

Weekly variations in soil water tension in banana plantation at $-20 \mathrm{~cm}$ and $-40 \mathrm{~cm}$ according to treatments with no-tillage and conventional tillage $(n=3)$. 
Figure 9.

Soil mineral nitrogen dynamics $\left(\mathrm{NO}_{3}^{-}\right.$and $\left.\mathrm{NH}_{4}^{+}\right)$in banana plantation according to treatments with no-tillage and conventional tillage $(n=3)$.

\section{Figure 10.}

Chlorophyll-meter readings in banana plantation according to treatments with no-tillage and conventional tillage $(n=3)$.

\section{Figure 11.}

Root density distribution in the soil profile eight months after banana planting $\left(T_{0}+8\right)$ according to treatments with no-tillage and conventional tillage $(n=3)$.
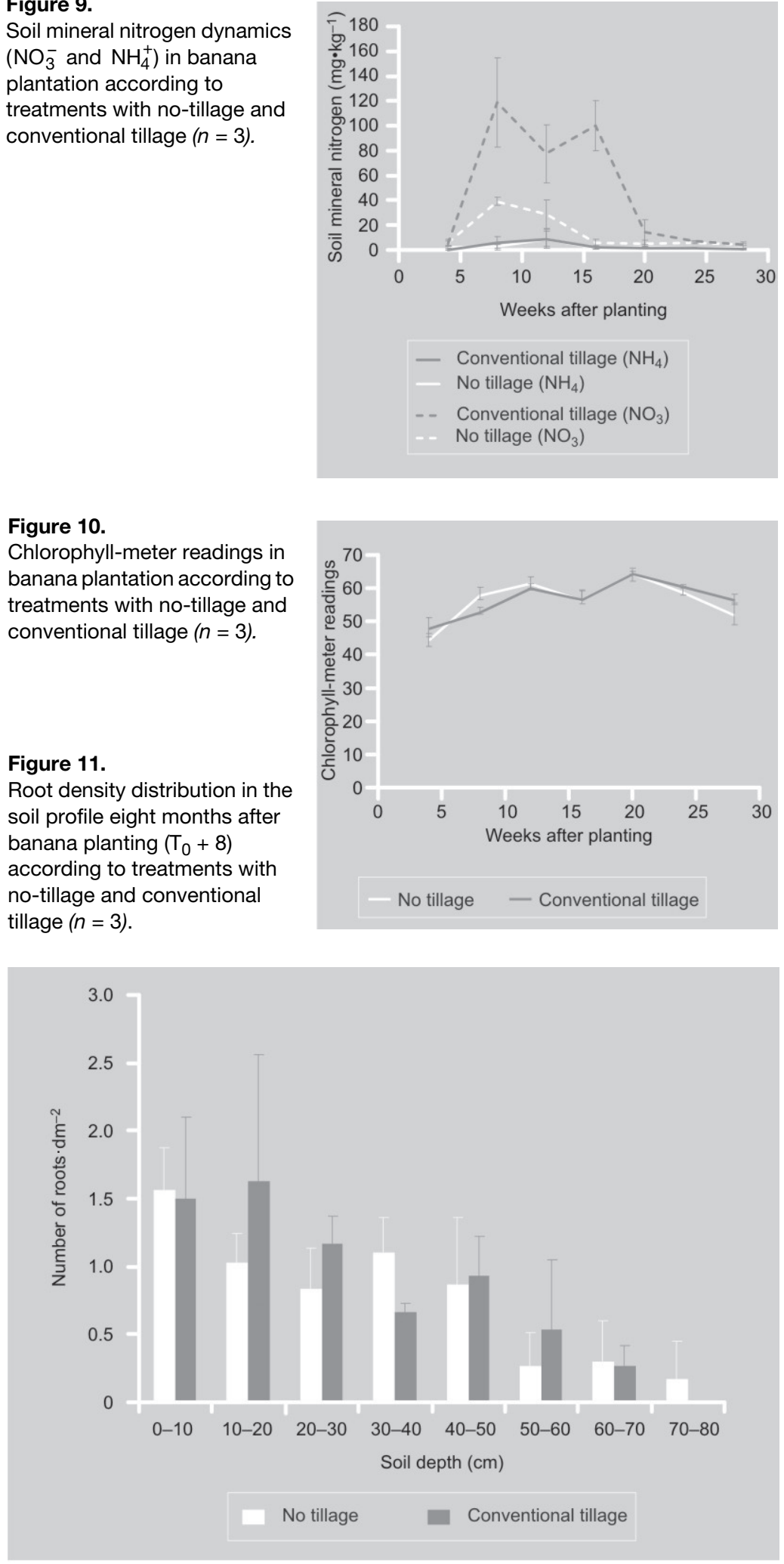

\section{Conclusions}

Conventional banana planting after tillage (conventional tillage) allowed short-term increase in porosity and hydraulic conductivity and decrease in penetration resistance of the soil but it did not improve root extension in the soil profile compared with notill banana planting on crop residue mulch (no-tillage). No-tillage improved soil biological properties (larger microbial biomass and greater functional richness of nematofauna), had less drying out of soil and led to better crop performance. Although differences between no-tillage and conventional tillage should decrease in the longer term because of the low frequency of tillage in the banana cropping system, no-till banana planting on crop residue mulch can be advised for banana growers.

\section{Acknowledgements}

This work was partly supported by an ENDURE (European Network for Durable Exploitation of Crop Protection Strategies) grant.

\section{References}

[1] Lal. R., Reicosky D.C., Hanson J.D., Evolution of the plow over 10000 years and the rationale for no-till farming, Soil Tillage Res. 93 (2007) 1-12.

[2] Lal R., Griffin M., Apt J., Lave L, Morgan M.G., Managing Soil Carbon, Science 304 (5669) (2004) 393.

[3] Caneil J., Bodet J.M., Simplification du travail du sol et rendement des cultures, Colloq. INRA 65 (1991) 63-82.

[4] Germon J.C., Taureau J.C., Thomas J.M., Effets des méthodes simplifiées de travail du sol sur les transformations de l'azote et leurs conséquences sur le lessivage des nitrates, Colloq. INRA 65 (1991) 125-154.

[5] Franzluebbers A.J., Tillage and residue management effect on soil organic matter. Effect of tillage on plant growth, in: Magdoff F., Ray R.W. (Eds.), Soil organic matter in sustainable agriculture, CRC Press, Boca Raton, USA, 2004. 
[6] Bockus W.W., Shroyer J.P., The impact of reduced tillage on soilborne plant pathogen, Annu. Rev. Phytopathol. 36 (1998) 485-500.

[7] Govaerts B., Fuentes M., Mezzalama M., Nicol J.M., Deckers J., Etchevers J.D., Figueroa-Sandoval B., Sayre K.D., Infiltration, soil moisture, root rot and nematode populations after 12 years of different tillage, residue and crop rotation managements, Soil Tillage Res. 94 (2007) 209-219.

[8] Sturz A.V., Carter M.R., Johnston H.W., A review of plant disease, pathogen interaction and microbial antagonism under conservation tillage in temperate humid agriculture, Soil Tillage Res. 41(1997) 169-189.

[9] Peigné J., Ball B.C., Roger-Estrade J., Davis C., Is conservation tillage suitable for organic farming? A review, Soil Use Manag. 23 (2007) 129-144.

[10] Okada H., Harada H., Effects of tillage and fertilizer on nematode communities in a Japanese soybean field, Appl. Soil Ecol. (2007) 35 582-598.

[11] Brmez M., Ivezic M., Raspudic E., Effect of mechanical disturbance on nematode communities in arable land, Helminthologia 43 (2) (2006) 117-121.

[12] Chan K.Y., An overview of some tillage impacts on earthworm population abundance and diversity - implications for functioning in soils, Soil Tillage Res. 57 (2001) 179-191.

[13] Alvarez C.R., Alvarez R., Short-term effects of tillage system on active soil microbial biomass, Biol. Fertil. Soil 31 (2000) 157-161.

[14] Khamsouk B., Impact de la culture bananière sur l'environnement. Influence des systèmes de cultures bananiers sur l'érosion, le bilan hydrique et les pertes en nutriments sur un sol volcanique de Martinique, ENSA Montp., Thesis, Montp., France, 2001, 214 p.

[15] Dorel M., Lombard K., Oliver R., Azote minéralisable et statut organique des andosols de Guadeloupe. Influence du milieu et des pratiques culturales, Etude Gest. Sols 12 (2005) 267-280.

[16] Dorel M., Roger-Estrade J., Manichon H., Delvaux B., Porosity and soil water properties of Caribbean volcanic ash soils, Soil Use Manag. 16 (2000) 133-140.

[17] Clermont-Dauphin C., Cabidoche Y.-M., Meynard J.-M., Effects of intensive monocropping of bananas on properties of volcanic soils in the uplands of the French West Indies, Soil Use Manag. 20 (2004) 105113.

[18] Virginia R.A., Wall D.H., How soil structure communities in the Antartic Dry Valleys, Bioscience 49 (1999) 973-983.

[19] Gupta V.V.S.R., Yeates G.W., Soil microfauna as bioindicators of soil health, in: Pankhurst C.E., Doube B.M., Gupta V.V.S.R., Biological indicators of soil health, CABI Publ., Wallingford, U.K., 1997.

[20] Mulder C., Schouten A.J., Hund-rinke K., Breure A.M., The use of nematodes in ecological soil classification and assessments concepts, Ecotoxicol. Environ. Saf. 62 (2005) 278-289.

[21] Bongers T., Bongers M., Functional diversity of nematodes, Appl. Soil Ecol. 10 (1998) 239-251.

[22] Ferris H., Bongers T., de Goede R.G.M., A framework for soil food web diagnostics: extension of the nematode faunal analysis concept, Appl. Soil Ecol. 18 (2001) 13-29.

[23] Neher D., Role of nematodes in soil health and their use as indicators, J. Nematol. 33 (4) (2001) 161-168.

[24] Yeates G.W., Bongers T., Nematode diversity in agroecosystems, Agric. Agrosyst.d Environ. 74 (1999) 113-135.

[25] Anon., World reference base for soil ressources: keys to reference soil groups of the World, in: ISSS Work. Group Ref. Base, World Soil Resour. Rep. no. 84, FAO, Rome, Italy, 1998.

[26] Anon., Guidelines for soil description, 4th ed., FAO, Roma, Italy, 2006.

[27] Amato M., Ladd J.N., Essay for microbial biomass based on ninhydrin-reactive nitrogen in extracts of fumigated soils, Soil Biol. Biochem. 200 (1988) 107-114.

[28] Seinhorst J. W., Modifications of the elutriation method for extracting nematodes from soil, Nematologica 8 (1962) 117-128.

[29] Yeates G., Bongers T., de Goede R.G.M., Freckman D.W., Georgieva S.S., Feedings habits in nematode families and genera - an outline for soil ecologists, J. Nematol. 25 (1993) 315-331.

[30] Bongers T., The maturity index: an ecological measure of environmental disturbance based on nematodes species composition, Oecologia 83 (1990) 14-19. 
[31] Barthelemy P., Boisgontier D., Lajoux P., Machines à bêcher, in: Choisir les outils de travail du sol, ITCF, Paris, France, 1987.

[32] Cattan P., Cabidoche Y.-M., Lacas J.-G., Voltz M., Effects of tillage and mulching on runoff under banana (Musa spp.) on a tropical andosol, Soil Tillage Res. 86 (2006) 38-51.

[33] Balesdent J., Chenu C., Balabane M., Relationship of soil organic matter dynamics to physical protection and tillage, Soil Tillage Res. 53 (2000) 215-230.

[34] Dorel M., Problèmes de préparation des sols en bananeraie. Cas des sols à halloysite, Fruits 46 (4) (1991) 419-427.

[35] Ferris H., Venette R.C., van der Meulen H.R., Scow K.M., Nematode faunal indicators of soil food web condition, J. Nematol. 30 (1998) 495-496.
[36] Ferris H., Matute M., Structural and functional succession in the nematode fauna of a soil food web, Appl. Soil Ecol. 23 (2003) 93-110.

[37] Chaussod R., Zuvia M., Breuil M.C., Hétier J.M., Biomasse microbienne et statut organique des sols tropicaux : exemple d'un sol vénézuélien des Llanos sous différents systèmes de culture, Cah. Orstom (Série Pédol.) 27 (1992) 59-67.

[38] Dorel M., Ozier-Lafontaine H., Pilotage de l'irrigation des bananeraies sur sols ferralitiques et sols vertiques en Guadeloupe: recherche d'indicateurs de l'état hydrique de la culture, Fruits 53 (1998) 17-26.

[39] Lecompte F., Ozier-Lafontaine H., Pagès L., An analysis of growth rates and directions of growth of primary roots of field-grown banana trees in an andisol at three levels of soil compaction, Agron. 23 (2003) 209-218.

Plantación de bananos sin trabajo del suelo sobre un rastrojo de residuos de cultivo: efecto sobre la calidad del suelo y sobre el funcionamiento del cultivo.

Resumen -- Introducción. En las Antillas francesas los plantadores consideran generalmente que es necesario efectuar periódicamente un trabajo del suelo para regenerar su porosidad y mantener así un fuerte rendimiento. Sin embrago en las plantaciones bananeras perennes de altitud, el suelo que jamás está trabajado, presenta mejores propiedades físicas y biológicas que en las plantaciones bananeras tratadas de modo convencional. Con el fin de determinar si el trabajo del suelo antes de la plantación es necesario para el buen funcionamiento de un cultivo de bananos ; así como para evaluar el efecto de la labor sobre la calidad del suelo, se comparó una plantación de bananos tras trabajar el suelo de modo clásico con la plantación directa de bananos sobre un rastrojo de residuos de cosecha, en parcela experimental. Material y métodos. La calidad del suelo se evaluó mediante indicadores como, por ejemplo, la porosidad, el estatus orgánico, la biomasa microbiana y la estructura de las poblaciones de nematodos. Se evaluó el funcionamiento del cultivo gracias al crecimiento de la planta, a la distribución de las raíces, así como a la disponibilidad del agua y del nitrógeno del suelo. Resultados. Constatamos que el trabajo del suelo redujo la biomasa microbiana del mismo así como el número de conjunto de especies funcionales de nematodos. El trabajo del suelo únicamente tuvo un efecto a corto plazo sobre la porosidad del suelo; y, no permitió un arraigamiento más profundo. A pesar de que la mineralización del nitrógeno orgánico del suelo fuese más elevada en el suelo trabajado convencionalmente, la nutrición de los bananos, en nitrógeno, no fue mejor; probablemente porque la elevada fertilización nitrogenada compensó las variaciones de la disponibilidad orgánica de nitrógeno en el suelo. Constatamos que el crecimiento de los bananos era mejor en el tratamiento sin suelo trabajado. Esto puedo explicarse por una desecación del suelo causado por dejar sobre la superficie del suelo el rastrojo de residuos de cosecha, en el tratamiento sin suelo trabajado. Conclusión. En relación con el clásico suelo trabajado, una plantación sin labor mejoró la calidad del suelo así como los rendimientos del cultivo.

Francia (Guadalup) / Musa (bananes) / cultivo / biología del suelo / Cerolabranza / desempeño de cultivos 